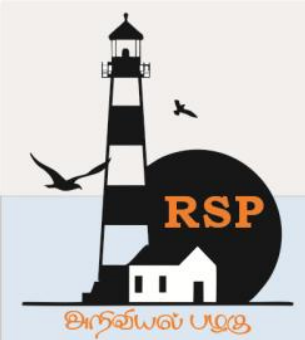

\title{
INTERNATIONAL RESEARCH JOURNAL ON
} ADVANCED SCIENCE HUB

\section{Virtual Discussion for Improving Motivation: A Christian Education Strategy against Covid-19 Pandemic Effect}

Sandy Ariawan ${ }^{1}$, Kristyana ${ }^{2}$, Nungky Nurprasetyaningsih ${ }^{3}$, Rusmi $^{4}$

${ }^{1}$ Lecturer, Dept. of Christian Education, STIPAK Malang, Jl. Janti Barat blok A no 48 Malang, East Java, Indonesia

${ }^{2}$ Lecturer, Dept. of Christian Education, STIPAK Malang, Jl. Janti Barat blok A no 48 Malang, East Java, Indonesia

${ }^{3}$ Teacher, SMKN 1 Gedangan, Jl. Raya Sumberrejo, Kab. Malang, East Java, Indonesia

${ }^{4}$ Teacher, SMKN 1 Nunukan, Jl. Sei Fatimah Nunukan Barat, North Kalimantan, Indonesia ariawan.sandy@yahoo.com ${ }^{1}$

\section{Abstract}

There was a big question about the transition to online learning on around the world, could it motiva student as good as the traditional methods? This study is aimed at finding out the effectiveness of virtu. discussion for improving motivation of students during the Covid-19 pandemic. A total of sixty Christic students of State Vocational High School Malang were involved in the study, separated in two classes. Tl first class was treated with virtual discussion method and the other class as a control class. This study used quasi-experimental research design, and analyzed using a paired sample t-test. The result obtained si 0.000 less than 0.05, showed a significant difference in the mean scores, indicated that virtual discussic was effective for improving motivation of students. From the finding, it is recommended to use virtu discussion in Christian education, against Covid-19 pandemic effect.

Keywords: Virtual Discussion, Motivation, Christian Education, Pandemic

\section{Introduction}

The Covid-19 pandemic has affected educational system worldwide. There was a big question about the transition to online learning on around the world, could it motivate student as good as the traditional methods? This study is aimed at finding out the effectiveness of virtual discussion for improving motivation of students during the Covid-19 pandemic.

The method of virtual discussion was a way of learning or teaching that was done in exchange between students and teachers, or students with students as discussion participants. In this method of virtual discussion was done in an orderly and directed way in small groups with the aim of obtaining an understanding, a mutual agreement and decision on a problem being addressed [1].

\subsection{Starting Virtual Discussion}

According to Djamarah, and Zain, the method of discussion was "how the lesson was presented, in which students were faced with an issue which can be a problematic statement or question to be discussed and solved together." [2] Inside this method of discussion virtually was expected to have interactions between two or more individuals involved, exchanging each other's experiences, giving information, solving problems and expected everything was active, there was nothing passive as a listener only, especially in Christian education [3]. 
The method of virtual discussion was a way of presenting lessons in which teachers provide opportunities for students (groups of students) to conduct scientific virtual discussions to collect opinions, to make conclusions or to prepare various alternatives to solving problems. From this virtual discussion, students were expected to be active, gave and received feedback from other groups [4].

If teachers wanted maximum student involvement in the virtual discussion, then the number of virtual discussion group members needed to be considered. The maximum number of virtual discussion group members was 3-7 members. From the observation, the virtual discussion group whose number of members is 3-7 people, the alleged members were less fully participated or passive just listening to around 1-2 people [5]. In the virtual discussion, it would be better if the number of members was relatively small allowing each student to have the opportunity to participate or become active. Topics or issues in virtual discussions should be relevant to students' interests to optimally encourage students' mental and emotional involvement [6]. Through the use of virtual discussion, students would have the opportunity to exercise skills that were communication skills and ability to develop a thinking strategy in solving problems [7].

Success in the method of virtual discussion depended heavily on the group members themselves in taking advantage of the opportunity to participate in the learning of how to respond and answer questions from other groups [8]. The role of a leader in the virtual discussion group was very important, which was tasked with clarifying unclear topics. If the virtual discussion was not running, the leader of the discussion was obliged to take the initiative by throwing ideas that could provoke discussion of participants. Similarly, if the opinions were distorted from the main topic then the leader of the virtual discussion tasked with returning talks according to the main topic.

Having a general knowledge of the issues discussed was a prerequisite for each participant to be able to brainstorm. The discussion would not be successful while the participants of the discussion did not have the problem discussed [9]. In formal virtual discussions, to equip the knowledge of participants, presented in advance the problems compiled by one of the participants of the discussion. The purpose of presenting the problem was to open the participants' insight and mind to be able to give his opinion [10].

\subsection{Fun Learning with Virtual Discussion}

Virtual discussion could be fun, because the atmosphere is more vivid. The students lead attention or mind to the problem that was being discussed. So the student participation in this method was better. The students practiced critical to consider the opinions of his friends, then determined the attitude, accepted, rejected or not argued at all. Virtual discussion could raise the achievement of individual personalities, such as: attitude of tolerance, democracy, critical thinking, systematic, patient and so on. Students were trained to learn to comply with the rules and ordinances like in a deliberation, not stuck in the minds of individuals who were sometimes wrong, prejudiced and narrow [11].

Virtual discussion also helped students to make better decisions. Conclusion as the results of discussions would be easily understood, because they followed the process of thinking before it came to a conclusion.

In small virtual discussion groups, classes were divided into several small groups of 4-5 students. The virtual room was arranged so that students can face each other easily. They could use free application such as: Google Hangouts Meet, Zoom, Webex Meet, Free Conference Call, etc. Discussions were held in the middle of the lesson or at the end of the lesson with the intent to sharpen understanding of the lesson frameworks, clarify the mastery of subjects or answer questions. The expected learning result was that all individuals compare their possible perception of the lesson material, comparing interpretations, so that mistakes could be avoided.

Other alternative, a class was divided into several small groups of $3-6$ students. Each small group carried out virtual discussions with specific problems. Teacher explained the outline of the problem to the group. Then each group (syndicate) started finding an agreement on the completion answer. To facilitate virtual discussions, teachers could provide relevant references or sources of information. Each group presented the conclusion 
of its discussion in the plenary proceedings to be discussed.

Virtual discussion as a teaching method was more suitable and necessary when teachers want to give students the opportunity to express their ability, think critically, assess their role in discussion, look at the problems of their own experiences and lessons gained at school, motivate, and further study. Through virtual discussion could be developed skills clarifying, classifying, drafting hypotheses, interpreting, drawing conclusions, applying theories, and communicating opinions. Besides, the method of discussion could train the attitude of students to appreciate the opinions of others, to train the courage to express the seal, to defend the opinion, and to give rational respect to the opinions that are met.

Some things to note in implementing the virtual discussion methods, among others: formulation of problems or problems discussed to be done together with the students, explain the nature of the problem with the purpose of why the problem was chosen to discuss, student role settings that include feedback, suggestions, opinions, questions, and answers arising to solve the problem, notifying the order of discussion, direction of talks to fit the objectives, giving students guidance to take conclusions.

The general learning needs in virtual discussion steps could be implemented with simple procedures, as follows: clearly formulate problems, form virtual discussion groups, choose discussion leaders (chairmen, secretaries, reporters), arrange the online application, facilities, and so on according to the purpose of discussion. The duties of the virtual discussion leader include: organizing and directing virtual discussions, organizing "traffic" talks, conduct discussions. Each member of the discussion should know exactly what to discuss and how to discuss it.

Virtual discussions should run in a free atmosphere, each member knows that they have the same talk rights. Teachers gave reasons or explanations to the report.

\subsection{Motivation in Learning}

The motivation came from the word "motive" which means as an effort to encourage someone to do something. Motifs could be said to be the driving force in and in the subject to carry out certain activities in order to achieve the objectives. Motifs become active at certain times, especially when the need to achieve goals is very perceived or urgent to be achieved.

It was also said that motivation was a mental drive that moves and directs human behavior, including learning behaviors. In the motivation contained desire that activates, moves, channeled, and directs the attitudes and behaviors of individual learning.

While Slavin argued that in simple language, motivation was something that causes you to step in, keep you going, and determine where you are trying to move [12]. Motivation is always related to a purpose. A student would succeed in achieving his or her learning achievement when supported by a very strong motivation for study. In this regard, it said that there are 3 (three) motivational functions: First, encouraging people to do, so as a mobilizer or a motor that releases energy. The motivation in this case was the driving force of each activity to be performed; Second, to determine the direction of action, namely towards the goal to be achieved. Thus motivation could give direction and activities that must be done according to the formulation of its purpose; Third, to select the deed, which was to determine the deeds that must be done that are compatible in order to achieve the objectives, by putting together actions that are not beneficial to the purpose. A student, who would face the exam in hopes of graduating, would certainly do the learning and never wasting his time [13].

\section{Method}

This study applied the quasi-experimental design with two groups, the experimental group and control group. The respondents are sixty high school students of Malang State Vocational. All respondents were devided into 2 different classes. One class would get treatment in the form of virtual discussion method, while the other class did not get treatment and served as a control class. Prior to the $\mathrm{t}$ analysis, the pre-requite test for normality had been conducted. Then, data were analyzed by using paired sample T-Test. Statistical calculation was aided by the SPSS software program. 


\section{Results}

Table.1. Reliability Statistic

\begin{tabular}{|c|c|}
\hline $\begin{array}{c}\text { Cronbach's } \\
\text { Alpha }\end{array}$ & N of Items \\
\hline .928 & 10 \\
\hline
\end{tabular}

Based on the table 1, Cronbach's Alpha obtained 0.928. It meant that the instrument reliabel.

\section{Table 2. Tests of Normality}

\begin{tabular}{|l|c|c|c|c|c|c|}
\hline \multirow{2}{*}{} & \multicolumn{3}{|c|}{$\begin{array}{c}\text { Kolmogorov- } \\
\text { Smirnov }\end{array}$} & \multicolumn{3}{c|}{ Shapiro-Wilk } \\
\cline { 2 - 7 } & $\begin{array}{c}\text { Statis } \\
\text { tic }\end{array}$ & Df & Sig. & $\begin{array}{c}\text { Statist } \\
\text { ic }\end{array}$ & Df & Sig. \\
\hline PreTest & .231 & 15 & .216 & .953 & 15 & .355 \\
\hline $\begin{array}{l}\text { PostTe } \\
\text { st }\end{array}$ & .194 & 15 & $.230^{*}$ & .875 & 15 & .144 \\
\hline *. This is a lower bound of the true significance. \\
\hline \\
a. Lilliefors Significance Correction \\
\hline
\end{tabular}

In test of normality with Shapiro-Wilk, it appeared that the number of significance for pretests and post-test is entirely above 0.05 . This meant that the distributed data was normal and was eligible for a test Paired Sample T-Test.

\section{Table 3. Paired Samples Statistics}

\begin{tabular}{|l|c|c|c|c|c|}
\hline & & & & \multicolumn{1}{c|}{$\begin{array}{c}\text { Std. } \\
\text { Std. } \\
\text { Error } \\
\text { Mean }\end{array}$} \\
\hline \multirow{2}{*}{$\begin{array}{l}\text { Pair } \\
1\end{array}$} & Pretest & 52.4200 & 30 & 11.25331 & 1.76215 \\
\cline { 2 - 7 } & Posttest & 83.5667 & 30 & 7.32772 & 1.12694 \\
\hline
\end{tabular}

In the table 3 appeared that the average value for pre-tests is 52.42. While the average value of post-test is 83.5667 .

The table 4 could be noted that the value of Sig. (2-tailed) is $0.000<0.05$. This indicated that there was a significant average difference between pretests and post-test results, which means the use of virtual discussion methods in Christian education is proven effective.

Table 4. Paired Samples Test

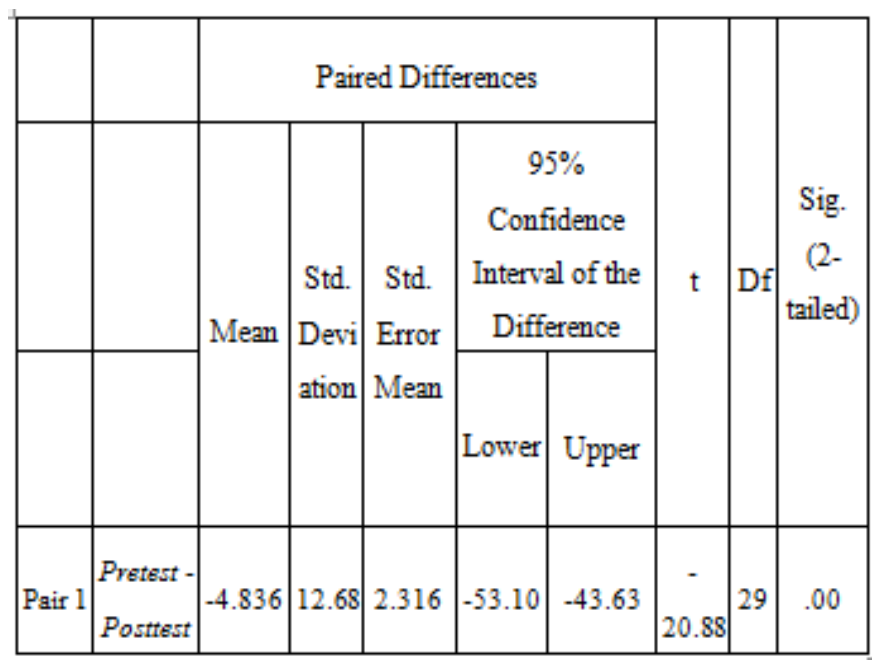

\section{Discussion}

Besides the advantages that had been raised, the method of virtual discussion did not escape the weaknesses, such as: virtual discussions were generally mastered by students who love to talk. Much time was spent, but the results were sometimes not as expected. For students who did not participate actively there was a tendency to escape responsibility. It also could not be worn in large groups [14].

How to overcome the weaknesses of other discussion methods: First, the virtual discussion was given to students and arranged in turns; Second, the teachers should not fully entrust the leadership of virtual discussions on students, need guidance and control; Third, the teachers also participated in the discussions; Forth, the students had a turn of speaking and other students learned to be patient listening to their friends' opinions; Fifth, optimize your existing time to get the desired results [15].

Each student in learning when using the method of virtual discussion was expected to engage actively in discussions to seek comprehension in various aspects of learning. If a student played an active role, it would be able to gain optimal learning outcomes. For teachers, in order to be able to master the use of the method of virtual discussion well required exercise systematically because the methods of virtual discussion instill discipline of students and increase knowledge in 
www.rspsciencehub.com

the opinion and draw a conclusion. In other words, teacher domination in the discussion must be reduced so that opportunities are available for students to participate actively. Through virtual discussion the group was expected to think critically and be able to express their thoughts and feelings well.

\section{Conclusions}

Based on the result of the study, it can be concluded that virtual discussion is able to improve motivation of students in Christian education. It is recommended to use virtual discussion during the pandemic and against the Covid-19 pandemic effect.

\section{Acknowledgement (Optional)}

Gratitude for the support of the principal of State Vocational High School 1 Gedangan Kabupaten Malang and State Vocational High School 1 Nunukan.

\section{References}

[1] Schmid, Kendra K. (2013). Virtual Discussion for Real Understanding: The Use of an Online Discussion Board in an Introductory Biostatistics Course. Technology Innovations on Statistics Education, 7(1)

[2] Djamarah, Syaiful Bahri, and Aswan Zain "Strategi Belajar Mengajar," Jakarta: Rineka Cipta, (2010)

[3] Ariawan, S. (2019). Countering Zeitgeist of Self-Centered through Role Playing Methods among Junior High School Students. International Journal of Education and Curriculum Application, 2(3), 44-49.

https://doi.org/10.31764/ijeca.v2i3.2143

[4] Weisskirch, Robert S. (2003). Virtual Discussion: Understanding College Students' Electronic Bulletin Board Use. The Internet and Higher Education, 6(3), 215-225.

https://doi.org/10.1016/S10967516(03)00042-3

[5] Yamat, H. (2013). Voicing on Virtual and Face to Face Discussion. TOJET: The Turkish Online Journal of Educational Technology, 12(2).
Volume 02 Issue 07 July 2020

[6] Lin, Michelle and Jonathan Serbino (2015). Creating a Virtual Journal Club: A Community of Practice Using Multiple Social Media Strategies. Journal of Graduate Medical Education, 7(3). https://doi.org/10.4300/JGME-D-1500070.1

[7] Rovai, A.P (2017). Facilitating Online Discussions Effectively. The American Journal of Distance Education, 15(1), 7-23.

[8] Pendry, L.F (2015). Individual and Social Benefits of Online Discussion Forums. Computers in Human Behavior, 50(1), 211220.

[9] Seethamraju, Ravi (2014). Effectiveness of Using Online Discussion Forum for Case Study Analysis. Education Research International.

[10] Ariawan, S (2018). The Effectiveness of Cooperative Learning Method (Student Team Achievement Divisions) in Christian Education. International Journal of Education and Curriculum Application, 1(3), 45-50. https://doi.org/10.31764/ijeca.v1i3.2128

[11] Baker, David L (2011). Designing and Orchestrating Online Discussions. Merlot Journal of Online Learning and Teaching, 7(3), 401-411.

[12] Slavin, Robert E. "Cooperative Learning Teori, Riset dan Praktik," Bandung: Nusa Media, (2011).

[13] Ariawan, S. "Kreativitas Mengajar dan Implementasi Konsep Pastor-Teacher," SulSel: CV. Mitra Ilmu, (2020) http://doi.org/10.31237/osf.io/xe95j

[14] Schaefer, RA Bull, L. Erskine (2012). Virtual Team Meetings: Reflections on a Class Exercise Exploring Technology Choise. Journal of Management Education, 36(6), 777-801.

[15] Bogler, R (2013). Transformational and Passive Leadership: An Initial Investigation of University Instructors as Leaders in a Virtual Learning Environment. Educational Management Administration and Leadership, 41(3), 372392. 